\title{
When an Unexpected Diagnosis Occurs: a Vaginal Premenopausal Sarcoma
}

\section{Quando um diagnóstico inesperado ocorre: um sarcoma vaginal na pré-menopausa}

\author{
Pedro Marcos-Figueiredo ${ }^{1}$ Diana de Sousa da Costa Moreira ${ }^{2}$ Manuel Gonçalves Morim ${ }^{3}$ \\ Júlia Leite Pereira $^{3}$ Lurdes Silva Salgado ${ }^{2}$
}

${ }^{1}$ Serviço de Ginecologia/Obstetrícia, Hospital Senhora da Oliveira Guimarães, Guimarães, Portugal

2 Serviço de Radiologia, Instituto Português Oncologia do Porto Francisco Gentil, Porto, Portugal

${ }^{3}$ Serviço de Ginecologia/Obstetrícia, Centro Hospitalar da Póvoa de Varzim/Vila do Conde, Póvoa de Varzim, Portugal

Address for correspondence Pedro Marcos Figueiredo, MD, Hospital Senhora da Oliveira Guimarães, Rua dos Cutileiros 114, Guimarães, Portugal (e-mail: pedrofigueiredoficial@gmail.com).

Rev Bras Ginecol Obstet 2018;40:47-52.

\begin{abstract}
Vaginal cancer is a rare entity. The evidence on its management resides mostly in clinical cases or small case series. Of the histological types, the most frequent is the squamous cell carcinoma, followed by adenocarcinoma. But what to do when identifying an even more infrequent sarcoma in a premenopausal woman? In this study, we describe the case of a 53-year-old woman presenting with metrorrhagia for two months, who was evaluated after an intense episode. A necrotic and ulcerative vaginal swelling was documented and then submitted to biopsy, which revealed a vaginal sarcoma. The patient was referred to radiation therapy with $50 \mathrm{~Gy}$ (aiming to

\section{Keywords}

- vaginal cancer

- vaginal sarcoma

- pelvic radiotherapy

- postcoital bleeding

- gynecologic hemorrhage control the symptoms and to cause tumor reduction for posterior pelvic exenteration with intraoperative radiotherapy) and developed an extra-pelvic metastization at the end of the treatment, which caused a fast negative outcome. Despite the initial poor prognosis, a chemo-irradiation or primary surgery regimen might have achieved (although with greater side effects) a better survival. This case-report entails a discussion about the strategies to manage vaginal sarcoma in advanced stage and in premenopausal women.

\section{Resumo \\ Palabras Clave \\ - cancro vaginal \\ - sarcoma vaginal \\ - radioterapia pélvica \\ - coitorragia \\ - hemorragia ginecológica}

O cancro vaginal é uma doença rara. A evidência para a sua abordagem reside fundamentalmente em casos clínicos ou pequenas séries de casos. Dentre os tipos de cancro histológicos, o mais frequente é o carcinoma espinocelular, seguido do adenocarcinoma. Mas o que fazer em presença de um sarcoma ainda mais raro numa mulher pré-menopáusica? No presente estudo, descrevemos o caso de uma mulher de 53 anos apresentando metrorragia por dois meses, avaliada após um episódio intenso. Foi então documentada uma tumefacção vaginal necrótica e ulcerativa, submetida a biópsia, que revelou um sarcoma vaginal. A paciente foi encaminhada para radioterapia
\end{abstract}

received

July 20, 2017

accepted

November 11, 2017
DOI https://doi.org/

10.1055/s-0037-1615293. ISSN 0100-7203.
Copyright $(2018$ by Thieme Revinter

Publicações Ltda, Rio de Janeiro, Brazil
License terms

(ㄷ) (i) $\ominus$ (5) 
com 50 Gy (com os objetivos de controlo da sintomatologia e de redução tumoral para posterior exenteração pélvica com radioterapia intraoperatória) e desenvolveu, ao final do tratamento, um quadro de mestastização extra pélvica, que ocasionou um desfecho negativo rápido. Apesar do mau prognóstico inicial, um esquema de quimiorradiação ou cirurgia primária poderiam ter alcançado (ainda que com maiores efeitos laterais) uma maior sobrevivência. Este estudo de caso aborda uma discussão sobre as estratégias de abordagem do sarcoma vaginal em estádios avançados e na mulher pré-menopáusica.

\section{Introduction}

The primary vaginal cancer comprises approximately only $3 \%$ of all malignant neoplasms of the female genital tract. ${ }^{1}$ This type of cancer is rare, and a metastatic disease or local extension from adjacent gynecologic structures to the vagina is not uncommon. ${ }^{2}$ Consequently, it must be excluded before assuming a primary neoplasm.

The most common clinical presentation of vaginal cancer is vaginal bleeding, typically postcoital or postmenopausal. $^{3,4}$ Many women are asymptomatic. A vaginal mass may also be noted by the patient. ${ }^{3,4}$ Other potential symptoms are related to local extension of the disease. The posterior wall of the upper one-third of the vagina is the most common site of primary vaginal carcinoma. ${ }^{4}$ The lesion may appear as a mass, a plaque or an ulcer.

Leiomyosarcomas, endometrial stromal sarcomas, malignant mixed Müllerian tumors and rhabdomyosarcomas are the major types of primary vaginal sarcomas. ${ }^{4}$ They represent less than $3 \%$ of all vaginal cancers. Less than 50 cases of vaginal leiomyosarcoma are reported in the literature. Still rare, the most common type of leiomyosarcoma is the embryonal rhabdomyosarcoma. ${ }^{5}$

Vaginal tumors may invade locally and disseminate by several routes: direct extension to pelvic soft tissue structures, lymphatic spread and hematogenous dissemination, depending on the stage and histological type. The most important variable affecting the prognosis is the stage at the time of presentation. The global poor survival rates (even lower in sarcomas) may reflect the higher proportion of vaginal tumors initially diagnosed at an advanced stage, and the potential for treatment complications that prevents aggressive therapy. ${ }^{4,6}$

\section{Case Description}

A 53-year-old premenopausal woman presented to the urgent care department with severe vaginal bleeding and a history of postcoital and intermenstrual bleeding over the previous two months. In her gynecological/obstetrical history, she had two pregnancies - one vaginal delivery and one ectopic, for which she underwent a salpingectomy at laparotomy. She was known to have no relevant medical history or concerns. Her father and mother died of lung and breast cancer, respectively.
At the physical examination, the patient weighed $66 \mathrm{Kg}$, appeared pale and lethargic, but otherwise well. The abdominal examination was normal. Upon speculum examination, an ulcerative and necrotic lesion was noted in the upper two thirds of the vagina, raising suspicion of neoplasia and, consequently, a biopsy was performed. The bimanual examination was painful, and the lesion was noted to be irregular, but it was not obliterating the fornices or reaching the cervix; the corpus and cervix of the uterus were mobile, not enlarged and no adnexal masses, inguinal or parametrial lymphadenopathies were palpable. Digital rectal examination found a normotonic sphincter and free rectal ampulla.

Foi aconselhado por um revisor colocar uma imagem da Ressonância Magnética original documentando a lesão. Já pedi para levantar o processo para a tirar mas dará tempo para acrescentar a imagem? Deve estar pronta nesta semana. The lesion had well defined limits, and it was reaching the bladder and cervix without invasion, without ureteric dilation, paravaginal or rectal involvement (-Fig. 1). Internal and external iliac lymphadenopathy was noted bilaterally (shortly after, guided MR biopsy-proven reactive). The uterus was normal in size, with a regular contour and $4 \mathrm{~mm}$ endometrium. The remaining thoracoabdominal exam was unremarkable.

The histological analysis of the tumor sample showed epithelioid cells with necrotic areas and high levels of mitosis - most likely a primary vaginal leiomyosarcoma and less likely a mixed Müllerian tumor-after immunohistochemical evaluation (CD31 negative, CD34 negative, CD10 occasionally positive, AE1/AE3 negative, AML positive, vimentin-positive, desmine-negative), highlighting a probable muscular neoplasia (-Fig. 2A and 2B).

After multidisciplinary team (MDT) review at an oncology institute, it was agreed to offer initial treatment with RT, then subsequent assessment to consider the possibility of pelvic exenterative surgery with intraoperative radiation therapy. It was agreed that management will increase the possibilities of cure, and not primary surgical resection, which also are amenable.

Within a week of the MDT review and prior to her first session of RT, the patient developed urinary frequency, constipation and uncontrolled pelvic pain despite analgesia. Upon examination, there were no recent changes, except for paracolpos infiltration on digital rectal examination. She commenced RT (total 50Gy) of the whole pelvis and vagina with external radiation delivered at 2Gy/day, IMRT (Intensity-Modulated Radiation Therapy) 5 


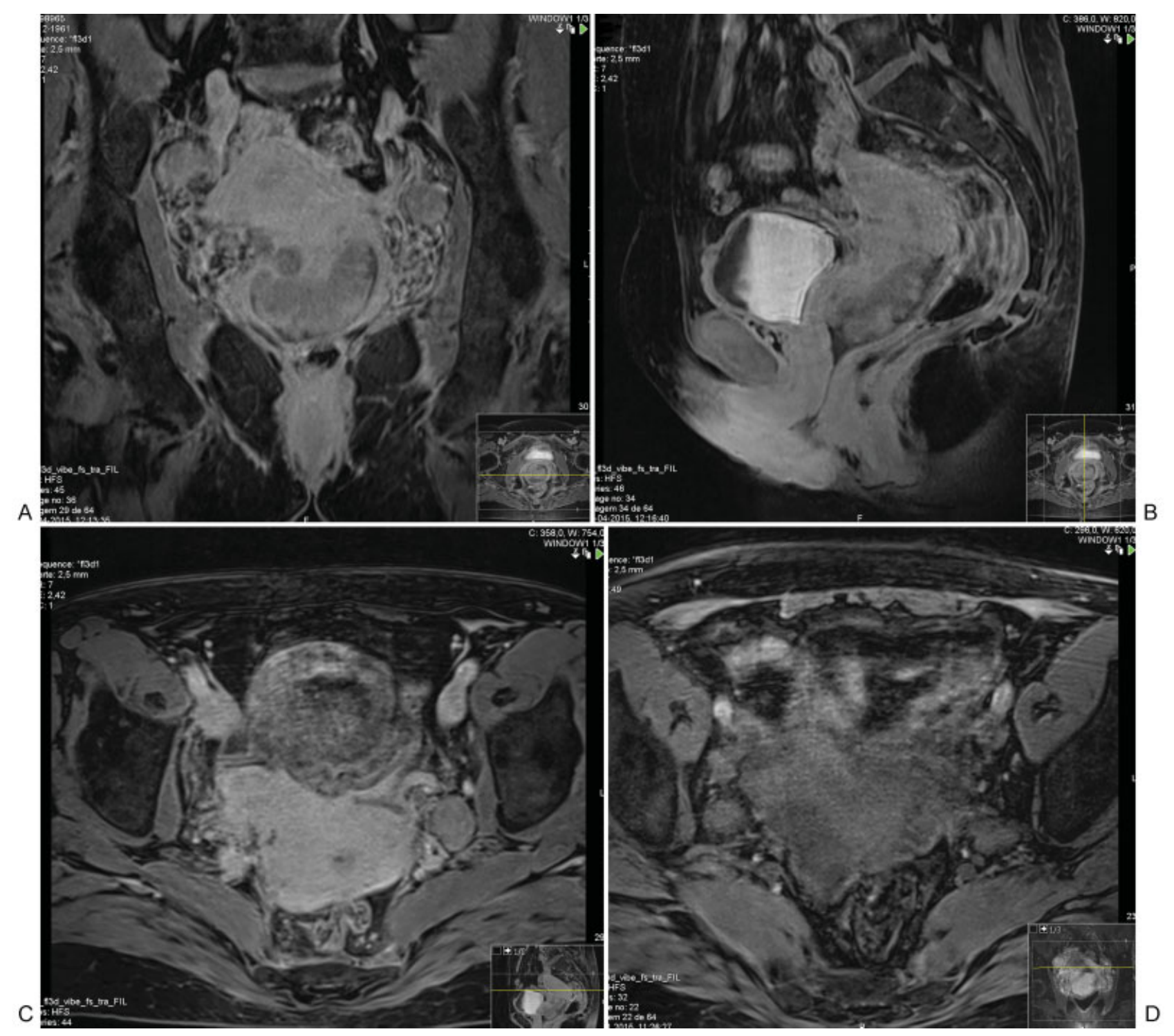

Fig. 1 Lesion limits, reaching the bladder and cervix.

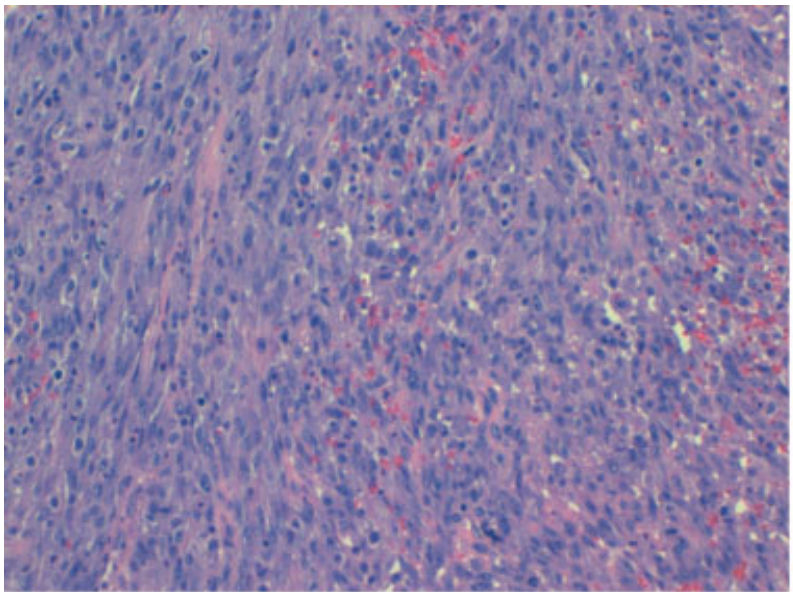

(A) HE $40 X$

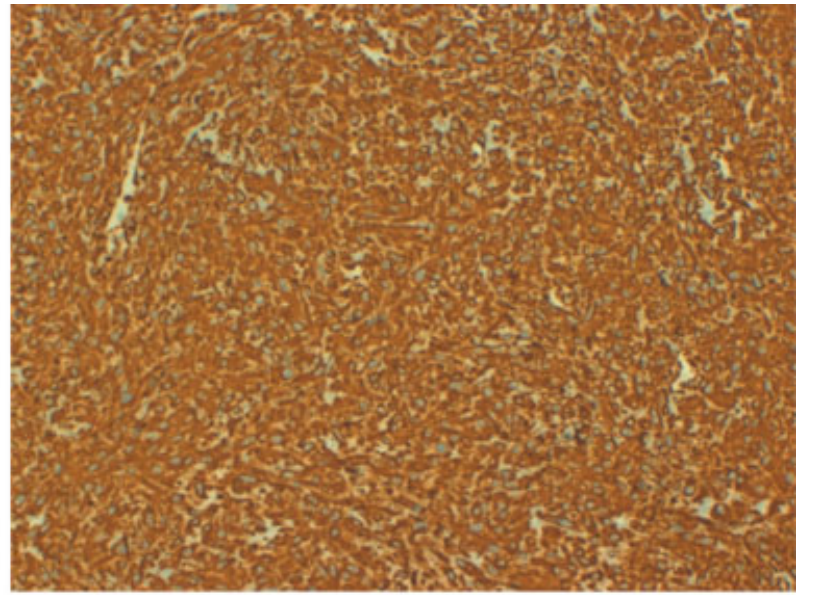

(B) Vimentin

Fig. 2 (A and B) Histology - Epithelioid cells with necrotic areas and high mitotic rate, most likely a leiomyosarcoma. 


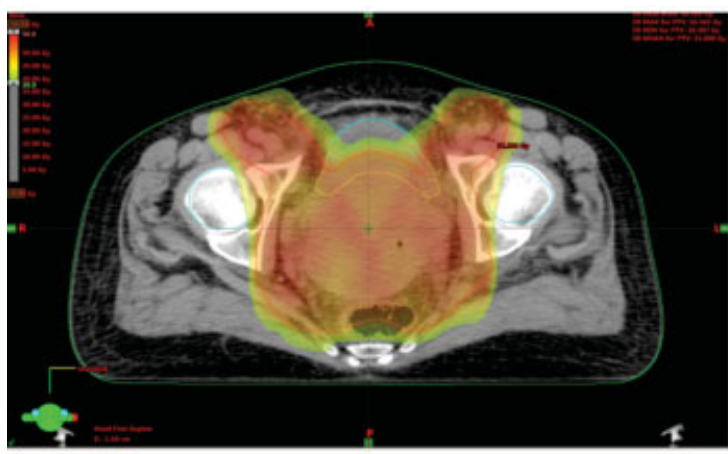

(A)

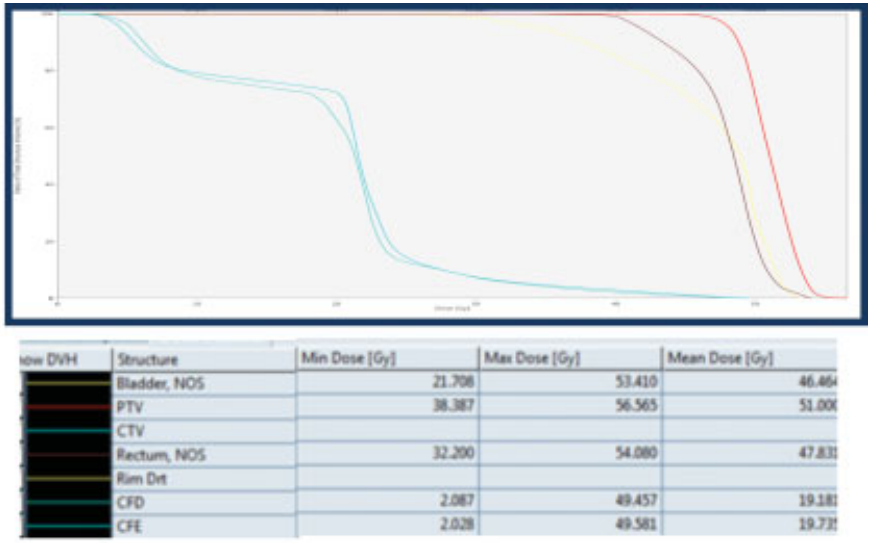

(B)

Fig. 3 (A and B) Dosimetric plan and dose-volume histogram.

times/week with diary portal vision during the first week, and after then, once per week ( - Fig. 3). Seven days later, the pelvic pain and constipation were controlled.

After two weeks of RT, 20 Gy had been administered and the patient reported an improvement in her appetite, lethargy and intermenstrual bleeding, despite the diagnosis of microcytic anemia of $8,1 \mathrm{~g} / \mathrm{dL}$, then managed with transfusion. The gynecological examination revealed large tumoral necrosis, and the patient felt able to manage on less painkillers and was commenced on oral doxycycline.

During the last week of RT, the patient developed lethargy and anorexia. No changes were found during the examination at this time, other than her weight had dropped by $5 \mathrm{~kg}$ to $61 \mathrm{Kg}$. The serum biochemistry revealed hypomagnesemia and a borderline potassium deficiency, which was treated with oral supplements. Finally, she completed $50 \mathrm{~Gy}$ of RT with average global state; maintaining weight $(61 \mathrm{Kg})$ and examination findings.

Two days later, she complained of epigastric/right hypochondrium pain and bowel subocclusion semiology, with worsening anorexia. She had slightly painful deep palpation of the right hypochondrium and epigastrium (suspected hepatomegaly) without signs of peritoneal irritation. She was tachycardic (130 bpm), but the remaining vitals were normal. In the thoracic X-ray, pulmonary metastasis was revealed (micro and macronodules of irregular limits) and an abdominal X-ray confirmed subocclusion. The progression of the disease was also documented in the serum samples, which revealed thrombocytopenia of $47,000 / \mathrm{uL}$, hyponatremia, hypomagnesemia and elevated liver parameters (aspartate transaminase [AST]/alanine transaminase [ALT] double the upper normal limit (UNL), total bilirubin $1.5 \mathrm{x}$ UNL, alkaline phosphatase $10 \mathrm{x}$ UNL, lactate dehydrogenase $6.8 \times \mathrm{UNL}$ ), raising concern of probable hepatic/ peritoneal metastasis.

The patient was admitted for supportive care, under a nil-by-mouth regimen, and with fluid resuscitation. During the subsequent MDT review, a decision was made to refer her care to palliative care. The patient passed away on the following day.

\section{Discussion}

Vaginal sarcoma is a very rare oncology malignancy, within the already infrequent vaginal cancer category.

The staging is clinical, based upon findings from physical examination cystoscopy, proctoscopy, and chest and skeletal radiography. ${ }^{6,8}$ An MRI can assist in determining the primary vaginal tumor size and local extent. Vaginal tumors are generally best seen on T2 imaging. ${ }^{9}$ Despite the fact that the majority of available evidence is for squamous cell carcinoma and adenocarcinoma, the positron emission tomographycomputed tomography (PET-CT) value appears to be useful to address metastization, mainly in advanced stages. ${ }^{10,11}$ The guided biopsy performed may have a role in cancer dissemination, but this appear to be very unlikely. In the first place, the lymphadenopathies were reactive (even in pathologic revision). Furthermore, we only found studies justifying this concern in uterine cancers, when morcelation is used. The International Federation of Gynecology and Obstetrics (FIGO) and the Tumor, Nodes, Metastasis (TNM) classification recommend a clinical staging system for vaginal cancer. ${ }^{6}$

With regard to global vaginal cancer, $37 \%$ of the patients are diagnosed at stage II, and $37 \%$ at stages III or IV. ${ }^{8}$ In the case of sarcomas, the outcome is even worse. ${ }^{4,6,8}$ In this case, due to the already advanced stage of the disease, the patients are often not candidates for surgery. Given the relatively poor outcomes with treatment using RT alone, chemoradiation is often administered, rather than RT. This is largely based on an extrapolation of the improved outcomes with chemoradiation for the treatment of locally advanced cervical cancer, but studies in vaginal cancer show that locoregional control rates are high after chemoradiotherapy, and radiation-related long-term side effects do not seem worse compared with RT alone. ${ }^{12-14}$ However, given the lack of high-quality data to inform the benefits of chemoradiation, RT is a reasonable alternative, particularly for patients who are not candidates for cisplatinbased chemotherapy, for whatever reason. ${ }^{4}$ The data to support this approach specifically for vaginal cancer is low-quality and largely limited to small retrospective series. ${ }^{12-16}$ The leiomyosarcoma treatment (more rare) is often extrapolated for 
squamous cell carcinoma. In the case herein described, the goal was to control the symptoms and reduce the tumor, allowing a possible curative pelvic exenterative surgery with less morbidity. Surgery as a primary treatment modality is associated with less favorable outcomes, with it being typically difficult to obtain negative margins in women with large or extensive lesions without compromise of the bladder or rectum. ${ }^{4} \mathrm{Neo}-$ adjuvant therapy is largely experimental. ${ }^{4}$

A total radiation dose of at least 70 to $75 \mathrm{~Gy}$ is generally recommended, with 45 to $50 \mathrm{~Gy}$ delivered with external beam radiation, and the additional radiation administered with intracavitary or interstitial brachytherapy radiation, depending on the thickness of the primary tumor. The external radiation should include the pelvic lymph nodes, vaginal tumor with a margin, vagina, and paravaginal tissues and inguinal lymph nodes, if the vaginal tumor is in the lower half of the vaginal canal. Brachytherapy radiation should immediately follow the completion of external radiation. ${ }^{4,17}$

The prognosis for patients with this malignancy has improved with the use of multimodal therapy, including surgery and chemotherapy. If chosen, the surgical approach requires a radical hysterectomy, upper or total vaginectomy, and bilateral pelvic lymphadenectomy. Patients in the early stages of vaginal cancer appear to have the best outcomes when treated this way. ${ }^{2-4}$ For some patients, radiotherapy (RT) alone could be an adequate treatment, particularly important with concomitant brachytherapy. Patients with more advanced disease are often not candidates for surgery. Given the relatively poor outcomes with treatment using RT alone, chemoradiation is often administered, rather than RT. However, the treatment options evidence a lack of highquality data and there are no randomized trials defining the treatment for vaginal cancer, given its rarity. ${ }^{4,6}$ Instead, the treatment management is extrapolated from cervical or anal cancers and should be individualized depending upon the location, size and clinical stage of the tumor. ${ }^{7}$ In addition, the treatment must consider the local anatomic constraints and psychosexual issues.

There is no treatment defined for vaginal sarcoma. Usually is surgery, as the most of others sites. For advanced gynecologic sarcomas, until now, and not possible to control by surgery (not resection possible), the management can be considered palliative, what include radiotherapy with or without chemotherapy. In the present case, the metastasis found and worse evolution are in accordance with advanced stage of the disease. This kind of evolution is common in cervix neoplasia in advanced stage. The authors tried to treat by radiotherapy aiming to increase the possibilities for successfull surgery with less comorbidity, which was proven not suitable for this neoplasia.

\section{Conclusion}

Vaginal sarcoma is a rare malignancy and the treatment plan should be individualized depending upon the location, size, and clinical stage of the tumor. For patients with more advanced disease, chemoradiation is suggested, rather than RT. ${ }^{4,12}$
In this case, with a poor prognosis, the expected evolution is minimal and the primary best treatment is still controversial. The current evidence on sarcomas is poor and related to case series or case-reports, usually with bad evolution. Nevertheless, a chemoradiation scheme or primary surgical resection might have a better outcome in terms of survival (although with more side effects), even with high morbidity and worst psychosocial impact, in the case of premenopausal women. Thus, these treatments should be considered in the future, as they seem to be the main recommendation of last case series available. $^{18}$

\section{Conflicts to Interest}

The authors declare to have no conflicts of interest.

\section{Acknowledgments}

The authors would like to thank Dra. Isabel Macedo Pinto, from Laboratório de Anatomia Patológica IMP.

\section{References}

1 Siegel RL, Miller KD, Jemal A. Cancer statistics, 2015. CA Cancer J Clin 2015;65(01):5-29. Doi: 10.3322/caac.21254

2 Dunn LJ, Napier JG. Primary carcinoma of the vagina. Am J Obstet Gynecol 1966;96(08):1112-1116. Doi: 10.1016/0002-9378(66) 90519-9

3 Livingston RC. Primary carcinoma of the vagina. Springfield, IL: C. C. Thomas; 1950

4 Karam A, Berek JS, Kidd EA. Vaginal cancer. 2017. https://www. uptodate.com/contents/vaginal-cancer. Accessed January 12, 2017

5 Hilgers RD, Malkasian GD Jr, Soule EH. Embryonal rhabdomyosarcoma (botryoid type) of the vagina. A clinicopathologic review. Am J Obstet Gynecol 1970;107(03):484-502

6 FIGO Committee on Gynecologic Oncology. Current FIGO staging for cancer of the vagina, fallopian tube, ovary, and gestational trophoblastic neoplasia. Int J Gynaecol Obstet 2009;105(01):3-4. Doi: 10.1016/j.ijgo.2008.12.015

7 Lian J, Dundas G, Carlone M, Ghosh S, Pearcey R. Twenty-year review of radiotherapy for vaginal cancer: an institutional experience. Gynecol Oncol 2008;111(02):298-306. Doi: 10.1016/j. ygyno.2008.07.007

8 Hacker NF, Eifel PJ. Vaginal cancer. In: Berek JS, Hacker NF, eds. Berek and Hacker's Gynecologic Oncology. 6th ed. Philadelphia, PA: Lippincott Williams \& Wilkins; 2015:608-624

9 Gardner CS, Sunil J, Klopp AH, et al. Primary vaginal cancer: role of MRI in diagnosis, staging and treatment. Br J Radiol 2015;88 (1052):20150033. Doi: 10.1259/bjr.20150033

10 Robertson NL, Hricak H, Sonoda Y, et al. The impact of FDG-PET/ $\mathrm{CT}$ in the management of patients with vulvar and vaginal cancer. Gynecol Oncol 2016;140(03):420-424. Doi: 10.1016/j. ygyno.2016.01.011

11 Bentivegna E, Uzan C, Gouy S, et al. [The accuracy of FDG-PET/CT in early-stage cervical and vaginal cancers]. Gynecol Obstet Fertil 2011;39(04):193-197. Doi: 10.1016/j.gyobfe.2011.02.008

12 Grigsby PW. Vaginal cancer. Curr Treat Options Oncol 2002;3(02): 125-130. Doi: 10.1007/s11864-002-0058-4

13 Samant R, Lau B, e C, Le T, Tam T. Primary vaginal cancer treated with concurrent chemoradiation using Cis-platinum. Int J Radiat Oncol Biol Phys 2007;69(03):746-750. Doi: 10.1016/j.ijrobp. 2007.04.015

14 Miyamoto DT, Viswanathan AN. Concurrent chemoradiation for vaginal cancer. PLoS One 2013;8(06):e65048. Doi: 10.1371/journal.pone. 0065048 
52 When an Unexpected Diagnosis Occurs Marcos-Figueiredo et al.

15 Frank SJ, Jhingran A, Levenback C, Eifel PJ. Definitive radiation therapy for squamous cell carcinoma of the vagina. Int $J$ Radiat Oncol Biol Phys 2005;62(01):138-147. Doi: 10.1016/j.jirobp.2004.09.032

16 Dalrymple JL, Russell AH, Lee SW, et al. Chemoradiation for primary invasive squamous carcinoma of the vagina. Int $\mathrm{J}$ Gynecol Cancer 2004;14(01):110-117
17 Orton A, Boothe D, Williams N, et al. Brachytherapy improves survival in primary vaginal cancer. Gynecol Oncol 2016;141(03): 501-506. Doi: 10.1016/j.ygyno.2016.03.011

18 Li L, Zhang R, Wu LY, et al. [Primary leiomyosarcoma of the vagina: a clinical analysis of 9 cases]. Zhonghua Fu Chan Ke Za Zhi 2012;47 (10):747-750 